\title{
Seasonal variation in water uptake patterns of three plant species based on stable isotopes in the semi-arid Loess Plateau
}

\author{
Jian Wang ${ }^{\mathrm{a}, \mathrm{b}}$, Bojie Fu ${ }^{\mathrm{a}}$, Nan Lu ${ }^{\mathrm{a}, *}$, Li Zhang ${ }^{\mathrm{c}}$ \\ a State Key Laboratory of Urban and Regional Ecology, Research Center for Eco-Environmental Sciences, Chinese Academy of Sciences, Beijing 100085, China \\ ${ }^{\mathrm{b}}$ University of Chinese Academy of Sciences, Beijing 100049, China \\ c State Key Laboratory of Vegetation and Environmental Change, Institute of Botany, Chinese Academy of Sciences, Beijing 100093, China
}

\section{H I G H L I G H T S}

- Seasonal variations of water uptake pattern were determined by dual stable isotopes $\left(\delta \mathrm{D}\right.$ and $\left.\delta^{18} \mathrm{O}\right)$ and MixSIAR model.

- Soil water in the $0-120 \mathrm{~cm}$ depth contributed $75-80 \%$ to the total water uptake in the growing season.

- Vitex negundo displayed larger degree of ecological plasticity to switch water between shallow and deep soil layers.

- Functionally dimorphic root systems were related to flexible water uptake pattern.

\section{A R T I C L E I N F O}

\section{Article history:}

Received 20 May 2017

Received in revised form 14 July 2017

Accepted 14 July 2017

Available online 19 July 2017

Editor: Jay Gan

\section{Keywords:}

Water uptake pattern

MixSIAR

Dual stable isotopes

Loess Plateau

Root distribution

\section{G R A P H I C A L A B S T R A C T}

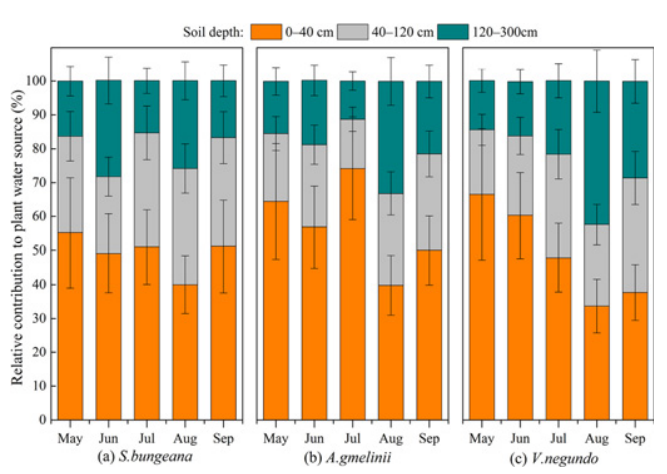

\section{A B S T R A C T}

Water is a limiting factor and significant driving force for ecosystem processes in arid and semi-arid areas. Knowledge of plant water uptake pattern is indispensable for understanding soil-plant interactions and species coexistence. The 'Grain for Green' project that started in 1999 in the Loess Plateau of China has led to large scale vegetation change. However, little is known about the water uptake patterns of the main plant species that inhabit in this region. In this study, the seasonal variations in water uptake patterns of three representative plant species, Stipa bungeana, Artemisia gmelinii and Vitex negundo, that are widely distributed in the semi-arid area of the Loess Plateau, were identified by using dual stable isotopes of $\delta^{2} \mathrm{H}$ and $\delta^{18} \mathrm{O}$ in plant and soil water coupled with a Bayesian mixing model MixSIAR. The soil water at the $0-120 \mathrm{~cm}$ depth contributed $79.54 \pm 6.05 \%$ and $79.94 \pm 8.81 \%$ of the total water uptake of S. bungeana and A. gmelinii, respectively, in the growing season. The $0-40 \mathrm{~cm}$ soil contributed the most water in July $(74.20 \pm 15.20 \%)$, and the largest proportion of water (33.10 $\pm 15.20 \%$ ) was derived from $120-300 \mathrm{~cm}$ soils in August for A. gmelinii. However, V. negundo obtained water predominantly from surface soil horizons $(0-40 \mathrm{~cm})$ and then switched to deep soil layers $(120-300 \mathrm{~cm})$ as the season progressed. This suggested that $V$. negundo has a greater degree of ecological plasticity as it could explore water sources from deeper soils as the water stress increased. This capacity can mainly be attributed to its functionally dimorphic root system. $V$. negundo may have a competitive advantage when encountering short-term drought. The ecological plasticity of plant water use needs to be considered in plant species selection and ecological management and restoration of the arid and semi-arid ecosystems in the Loess Plateau.

(C) 2017 Elsevier B.V. All rights reserved.

\footnotetext{
* Corresponding author.

E-mail address: nanlv@rcees.ac.cn (N. Lu).
} 


\section{Introduction}

Water plays crucial roles in plant productivity and species diversity in both natural and anthropogenic ecosystems (Porporato et al., 2004), and determines the distribution and ecological functions of vegetation. Plants are able to obtain water from various sources over time, depending on species, growth forms and environment conditions (Dawson et al., 2002; Eggemeyer et al., 2009; Grossiord et al., 2017; Yang et al., 2015; Evaristo and McDonnell, 2017). The spatial and temporal variations in water sources absorbed by plants are referred to water uptake pattern. Plant water uptake plays an important role in understanding and modeling hydrological processes at the soilvegetation-atmosphere interface (Chen et al., 2017; Sprenger et al., 2016; Vargas et al., 2017), and it provides critical insights into adaptive responses of plants to the changing environments (Dawson et al., 2002; Evaristo et al., 2016; Grossiord et al., 2017).

In arid and semi-arid ecosystems, soil moisture generated by precipitation is a limiting factor controlling vegetation structures and ecosystem processes (Gao et al., 2011; Moreno-de Las Heras et al., 2011). A healthy plant-soil ecosystem requires that water utilization by plants does not exceed the supply of soil water otherwise leads to water deficit (Chen et al., 2015). The capacity to adjust water use strategy along with the highly variable rainfall pattern and consequently soil water content is very critical for a plant to survive in these ecosystems (Wu et al., 2016; Grossiord et al., 2017). Plant derived the majority water from deep sources (e.g., deep soil water, groundwater) during the dry season while most water they used was derived from shallow sources supplied by upper soil layers during the wet season (Dawson and Pate, 1996; Asbjornsen et al., 2008). Multiple species living in the same habitat may have distinct water use patterns, making it possible for the species to coexist (Eggemeyer et al., 2009; Wu et al., 2016). This phenomenon may be attributed to hydrological niche segregation (Silvertown et al., 2015). Several studies showed that grass and herbs tended to continuously rely on water in the shallow soil layer across the growing season (Asbjornsen et al., 2008; Prechsl et al., 2015; Priyadarshini et al., 2016). In comparison, some studies showed that trees and shrubs tended to have the capacity to derive water sources from deeper soil layers (McCole and Stern, 2007; Wu et al., 2016). One of the reasons to explain the different water uptake patterns among varied plant functional types may relate to root morphology of plants. Some studies suggested that species with dimorphic roots have the capacity to switch water absorption zones between shallower and deeper soil layers (Dawson and Pate, 1996; Nie et al., 2010; Yang et al., 2015). The transposition capacity to absorb water sources from shallow to deep soil layers reflects plant ecological plasticity (Valladares et al., 2007). The greater ecological plasticity usually indicates a greater adaptation level to the environment. Therefore, a better understanding of plant water uptake patterns will improve our understanding of soil-plant interactions and guide ecosystem management practices in arid and semiarid areas such as selection of plant species for ecological restoration (Jian et al., 2015; Lü et al., 2017; Sprenger et al., 2016).

Water sources utilized by plants can be determined by many methods, such as root system excavation (Xu and Li, 2006), sap flow techniques (Delzon and Loustau, 2005), electrical resistivity (Mares et al., 2016), GIS tools (Howard and Merrifield, 2010), radioactive tracer tritium (Zhang et al., 2017). Although these methods could determine plant water sources in some extent, stable isotope technique provides an effective, powerful and nondestructive approach for identifying and partitioning the different potential water sources used by plants ( $\mathrm{Ma}$ and Song, 2016; Geris et al., 2017; Hardanto et al., 2017; Rothfuss and Javaux, 2017). Previous studies have proven that no isotopic fractionation of water occurs during water absorption by roots and transportation along the root-shoot conduit before transpiration starts in terrestrial plants (Brunel et al., 1995; Dawson et al., 2002; Ehleringer and Dawson, 1992), except for some coastal wetland species (Lin and Sternber, 1993) and woody xerophytes (Ellsworth and Williams,
2007), for which isotope fractionation occurs for hydrogen but not for oxygen during plant water uptake. Evaristo et al. (2017) reported that plant water sources quantification methods should consider the possible effects of hydrogen isotope fractionation. Nevertheless, the stable isotopes of $\delta^{2} \mathrm{H}$ and $\delta^{18} \mathrm{O}$ in water still can be used to determine water uptake patterns (Ehleringer et al., 1991; Li et al., 2007; Moreno-Gutiérrez et al., 2015; Swaffer et al., 2014; Yang and Fu, 2017).Although previous studies on water uptake patterns have been conducted in various ecosystems (Eggemeyer et al., 2009; Liu et al., 2010; Schwendenmann et al., 2015), there are still uncertainties regarding plant water uptake patterns (Eggemeyer et al., 2009; Yang et al., 2015). Only soil samples of $0-100 \mathrm{~cm}$ depths were collected and extracted as the main soil water sources in most studies (Meißner et al., 2012; Prechsl et al., 2015; Yang et al., 2015). This may underestimate the proportional contribution of soil water to plant water sources and correspondingly overestimate that of other water sources (e.g., spring, ground water, fog), particularly for shrubs and trees with deeper roots. Therefore, including deep soil sampling is necessary to improve the accuracy of water uptake quantification from varied sources and understanding of plant-water interactions (Querejeta et al., 2007; Wu et al., 2014).

The 'Grain for Green' project that was implemented in the Chinese Loess Plateau in 1999 is the largest vegetation restoration project in the world (Chen et al., 2015). Trade-offs between vegetation recovery and water depletion has attracted extensive attention (Chen et al., 2015; Jian et al., 2015; Wang et al., 2010). Unsuitable species selection for vegetation restoration leads to soil desiccation, vegetation degradation and difficulties in renewal and reforestation (Chen et al., 2008; Jian et al., 2015; Wang et al., 2010). Although some studies explored soil water migration (Yang and Fu, 2017) and plant water use strategy for natural and planted shrub (Lü et al., 2017), the difference between species and seasonal variations of water uptake pattern remain poorly understood in this region.

In this study, we examined the ecological plasticity of three plant species, Stipa bungeana (herb), Artemisia gmelinii (subshrub) and Vitex negundo (shrub) in terms of the water uptake patterns across the vertical soil profile during the growing seasons by using the isotopic technique. We hypothesized that the three species have different ecological plasticity in plant water uptake. The objectives of this study were to: (i) investigate the isotopic compositions of soil water and their vertical gradients along the soil profile, (ii) quantify the seasonal variations in water uptake patterns and identify their differences among the three species.

\section{Materials and methods}

\subsection{Study area}

This study was conducted in the Yangjuangou catchment in the central region of the Loss Plateau in Shanxi Province, China $\left(36^{\circ} 42^{\prime} 45^{\prime \prime} \mathrm{N}\right.$, $109^{\circ} 31^{\prime} 45^{\prime \prime} \mathrm{E}$ ). This catchment is a typical Loess hilly and gully region with a total area of $2.02 \mathrm{~km}^{2}$. The elevation is between 1050 and $1298 \mathrm{~m}$, and the slope gradients range from 10 to $30^{\circ}$ (Liu et al., 2012). This area is influenced by the semi-arid continental climate. The annual average precipitation and air temperature from 1960 to 2016 were $537 \mathrm{~mm}$ and $10{ }^{\circ} \mathrm{C}$, respectively (Fig. 1). Approximately $80 \%$ of the precipitation is concentrated between May and September, with large inter-annual variability. The growing season for most plant species starts in late April and ends by early October. Droughts frequently occur in spring and early summer because there is little precipitation during this period (Liu et al., 2012; Wang et al., 2012). The soil in the study area was loessial soil with the texture of silty loam, consisting of $25 \%$ clay $(<0.002 \mathrm{~mm}), 55 \%$ silt $(0.002-0.05 \mathrm{~mm})$ and $20 \%$ sand $(>0.05 \mathrm{~mm}$ ) (Li et al., 2003). The soil is vulnerable to erosion because of weak resistance. The soil in the study area was derived from loss, and the soil depth is usually 50-200 m depending on the topography 


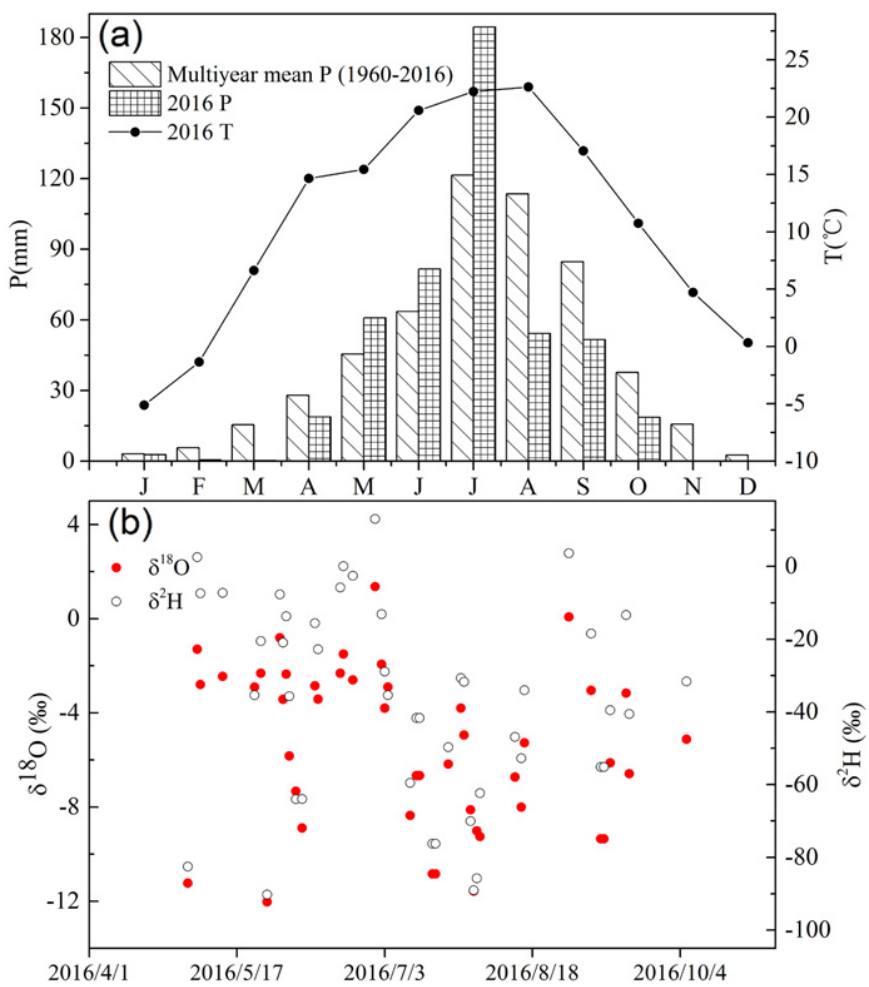

Fig. 1. The mean rainfall, temperature pattern and isotopic composition in rainwater: (a) the monthly variation of multi-year precipitation (1960-2016), temperature and precipitation in 2016; (b) the temporal variation of isotopic compositions in rainwater.

(Wang et al., 2012). Groundwater is buried deeply and soil water is the main water source for plants (Chen et al., 2008; Fan et al., 2016). The great majority of cultivated lands on the steep slopes in study area have been abandoned for natural and artificial re-vegetation as part of the 'Grain for Green' project. Currently, grassland is the dominant land cover on the hill-slopes (Liu et al., 2012).

\subsection{Experimental design and sample collection}

Soil, plant and rainwater samples were collected once a month from May to September 2016. S. bungeana is a widely distributed native perennial grass and usually occurs in middle or late successional stage during natural recovery from abandoned cropland. A. gmelinii is a perennial subshrub (e.g., a low-growing perennial plant having a woody lower stem) and a primary constructive species of natural grasslands on the hilly and gully region of the Loess Plateau. It usually occurs in middle successional stage during natural recovery. $V$. negundo is a perennial deciduous shrub that has been widely planted in ecological restoration on the Loess Plateau. Five plots of $2 \mathrm{~m} \times 2 \mathrm{~m}$ dominated by $S$. bungeana and A. gmelinii, respectively, and three plots of $5 \mathrm{~m} \times 5 \mathrm{~m}$ dominated by $V$. negundo were selected for study (Table 1). These plots for each species were close to each other to ensure that microenvironment of each plot was consistent, including soil condition, micro-geomorphology. The average basal diameter of $V$. negundo was $13.00 \mathrm{~mm}$. Three individuals of $V$. negundo were randomly chosen for plant sampling from three plots on each sampling date. Each plant sample was collected from four canopy directions at a height of approximately $100 \mathrm{~cm}$ above the ground. The phloem tissue of $V$. negundo was removed to avoid isotopic fractionation of xylem water and contamination by isotopic enriched water (Dawson, 1996; Querejeta et al., 2007). For S. bungeana and A. gmelinii, 8-10 individuals were selected as a sample, and three samples were collected from one plot on each sampling date. The root crown of each plant was collected from the surface soil because it correlates with the source water (Barnard et al., 2006; Wu et al., 2016). All of the plant samples were cut into 3-4 cm segments, immediately placed into glass vials with screw caps, sealed with polyethylene parafilm and kept frozen in a freezer $\left(-20^{\circ} \mathrm{C}\right)$ for isotopic analysis. A total of 45 plant samples for three species were collected during the study periods.

Soil samples were collected simultaneously with plant tissue sampling. Three soil cores were taken from three plots for $V$. negundo and one plot for $S$. bungeana and A. gmelinii on each sampling date at depths of $0-5 \mathrm{~cm}, 5-10 \mathrm{~cm}, 10-20 \mathrm{~cm}$, every $20 \mathrm{~cm}$ in the $20-120 \mathrm{~cm}$ range, every $40 \mathrm{~cm}$ in the $120-200 \mathrm{~cm}$ range, and at $50 \mathrm{~cm}$ intervals in the 200-300 cm layers. A power auger with the petrol engine-driven post driver (CHPD78, Christie Engineering Company, Sydney, Australia) was used to collect soil samples. Compared with the traditional hand auger, the post driver auger can obtain less compacted soil samples, improving the reliability of soil sample data. Soil samples were divided into two: one portion was stored in a freezer for isotopic analysis and the other was used to obtain gravimetric soil water content (SWC, \%) as determined by drying at $105^{\circ} \mathrm{C}$ for $24 \mathrm{~h}$. In addition, we investigated the root distributions of the three species by excavating soil layers per $10 \mathrm{~cm}$ until no root was found in the soil at the end of the growing season. The excavating depth of $S$. bungeana, A. gmelinii and $V$. negundo was $60 \mathrm{~cm}, 100 \mathrm{~cm}, 200 \mathrm{~cm}$, respectively. Root surface area $\left(\mathrm{m}^{2} / \mathrm{m}^{3}\right)$ was analyzed by WinRHIZO system (Regent Instruments, Quebec, Canada).

A polyethylene bottle and funnel were used to collect rainwater. A plastic ball was placed on the funnel to prevent evaporation (Yang et al., 2015). The rainwater samples were collected immediately after the rainfall terminated once a month from May to September and a total of 46 rainwater samples were taken. Similarly, rainwater samples were put into polyethylene bottles, wrapped with parafilm and stored in a freezer until subsequent isotopic analysis.

\subsection{Isotopic analyses}

Water in plant and soil samples was extracted using a cryogenic vacuum distillation system (LI-2100, LICA, Beijing, China). The extraction process required 1.5 to $3 \mathrm{~h}$ depending on the water content of the samples. The extraction efficiency was over $98 \%$, which was sufficient to obtain unfractionated water samples (Yang et al., 2015). Rain and extracted water were filtered using $0.22-\mu \mathrm{m}$ organic phase pin-type filters to eliminate impurities and organic contamination.

Isotopic measurements of water in plant tissues were conducted using an Isotope Ratio Mass Spectrometer (IRMS) system (MAT253, Thermo Fisher Scientific, Bremen, Germany). The measurement precision by IRMS was consistently $\pm 1 \%$ ofor $\delta^{2} \mathrm{H}$ and $\pm 0.2 \%$ for $\delta^{18} \mathrm{O}$. The isotopic ratios of rainfall and water extracted from soil samples were analyzed with an Isotopic Ratio Infrared Spectroscopy (IRIS) system (DLT100; Los Gatos Research, Mountain View, USA). The analytical precision of the liquid water measured by IRIS was $\pm 1.2 \%$ for $\delta^{2} \mathrm{H}$ and $\pm 0.3 \%$ or $\delta^{18} \mathrm{O}$. The analytical precision and accuracy of IRIS were similar to those of IRMS when measuring pure water (Brand et al., 2009). Extracting

Table 1

Basic information of sampled plant species.

\begin{tabular}{|c|c|c|c|c|c|}
\hline Species & Family & Life form & Height $(\mathrm{m})($ mean $\pm S D)$ & Leaf phenology & Vegetation coverage (\%) \\
\hline S. bungeana & Stipa & Tussock grass & $0.2 \pm 0.05$ & Perennial herb & $59-65$ \\
\hline A. gmelinii & Compositae & Subshurb & $0.6 \pm 0.08$ & Deciduous & $61-68$ \\
\hline V. negundo & Verbenaceae & Large shrub & $1.5 \pm 0.10$ & Deciduous & $62-70$ \\
\hline
\end{tabular}


water from plant tissues using cryogenic vacuum distillation can codistill organic materials (e.g., methanol and ethanol) that may affect the spectroscopy and lead to erroneous stable isotope values when analyzing with IRIS. However, trace amounts of organic matter did not affect the measurement results of IRMS method (West et al., 2010). The $\delta^{2} \mathrm{H}$ and $\delta^{18} \mathrm{O}$ for water extracted from soil samples $(\mathrm{n}=18)$ and rainwater $(\mathrm{n}=5)$ were measured with both IRMS and IRIS. The results showed that the mean discrepancies between IRMS and IRIS, were $0.34 \%$ for $\delta^{2} \mathrm{H}$ and $0.06 \%$ or $\delta^{18} \mathrm{O}$ in water from soil samples, and $0.34 \%$ ofor $\delta^{2} \mathrm{H}$ and $0.08 \%$ ofor $\delta^{18} \mathrm{O}$ in rainwater. There was no significant difference between IRMS and IRIS for $\delta^{2} \mathrm{H}(p=0.93>0.05)$ and $\delta^{18} \mathrm{O}(p$ $=0.93>0.05$ ) in soil water and rainwater. No contamination of organic matter was found in soil water and rainwater after quantifying using the spectral contamination identifier post-processing software (Los Gatos Research Inc., Mountain View, CA, USA) (Schultz et al., 2011; Zhao et al., 2011). Schultz et al. (2011) also found there was no contamination observed in soil water measurements analyzed with IRIS. In addition, previous studies reported that no discrepancies between the isotopic compositions of soil water measured using both IRIS and IRMS methods (Schultz et al., 2011; Zhao et al., 2011). Thus, we supposed that isotopic ratios of the two measurement methods would not affect our subsequent analyses. The calculation of isotopic ratios was expressed as follows:

$\delta X=\frac{R_{\text {sample }}}{R_{\text {standard }}}-1$

where $X$ represented ${ }^{2} \mathrm{H}$ or ${ }^{18} \mathrm{O}, R_{\text {sample }}$ and $R_{\text {standard }}$ represented the molar abundance ratios $\left({ }^{2} \mathrm{H} /{ }^{1} \mathrm{H}\right.$ and ${ }^{18} \mathrm{O} /{ }^{16} \mathrm{O}$, respectively) of the sample and standard (Standard Mean Ocean Water), respectively.

The weighted averages of $\delta^{2} \mathrm{H}$ and $\delta^{18} \mathrm{O}$ for precipitation per month $\left(\delta_{p, \text { mean }}\right)$ during the sampling dates were calculated as:

$\delta_{p, \text { mean }}=\frac{\sum_{i=1}^{n} \delta_{i} \times P P T_{i}}{\sum_{i=1}^{n} P P T_{i}}$

where $\delta_{i}$ and PPT $i$ represented the isotopic composition and amount of each precipitation event, respectively.

\subsection{MixSIAR model}

Groundwater was not used as a potential water resources because the table depth of groundwater in the Loess Plateau is buried deeply (40-100 m below soil surface), precluding any upward capillary flow into the root zone (Chen et al., 2008; Chen et al., 2007; Huang et al., 2013). The roots of plants had difficulty reaching the groundwater. Moreover, there was no surface runoff because of the high infiltration and no irrigation in the study area. Thus, soil water from different layers was regarded as the main potential resources for plant water uptake.

To identify the depths of water used by plants, stable isotopes of xylem water were compared with those of potential water sources, and the intersections between xylem water and potential water sources were detected. The intersection of the xylem water isotopic vertical line and the soil water isotopic profile was used to determine the main depth of the plant water uptake (Brunel et al., 1995; Yang et al., 2015). This graphical inference method was used as a preliminary judgment on water uptake depths.

The fractions of water sources used by plants was estimated by the Bayesian isotope mixing model MixSIAR (version 3.1.7), which incorporates uncertainties associated with multiple sources, discrimination factors (Stock and Semmens, 2013). The raw xylem isotope values $\delta^{2} \mathrm{H}$ and $\delta^{18} \mathrm{O}$ of three plant species were used as mixture data inputs into MixSIAR. The averages and standard errors of isotope values $\left(\delta^{2} \mathrm{H}\right.$ and $\left.\delta^{18} \mathrm{O}\right)$ from various soils horizons $(0-5,5-10,10-20,20-40,40-60$, $60-80, \quad 80-100, \quad 100-120, \quad 120-160,160-200, \quad 200-250$ and $250-300 \mathrm{~cm}$ ) were used as source data and input into MixSIAR. The source data had no concentration dependence. Individual effects as a random occurrence were included in all analyses. The discrimination data were set to zero for both $\delta^{2} \mathrm{H}$ and $\delta^{18} \mathrm{O}$ because isotopic fractionation did not occur during plant water uptake (Brunel et al., 1995; Dawson and Ehleringer, 1991). The run length of the Markov chain Monte Carlo (MCMC) was set to 'long' (chain length = 300,000; burn $=200,000$; thin = 100; chains = 3). MCMC was used to converge on the posterior distributions of all the variables in the model. It was essential to determine that the model had converged before accepting the output of MixSIAR. Gelman-Rubin and Geweke diagnostic tests were used to determine whether the model was close to convergence (Stock and Semmens, 2013). 'Residual only' was specified as the error structure in the model. The uninformative prior was set in the model. Water uptake patterns did not necessarily match the root distribution (Thorburn and Ehleringer, 1995) unless sufficient water in shallow soil layers generated by rainfall met vegetation requirements (Knight, 1999; Liu et al., 2011). Previous study found that the maximum water utilization depth of $S$. bungeana and A. gmelinii could reach $300 \mathrm{~cm}$ in the study area (Fan et al., 2016; Wang et al., 2002).V. negundo had larger lateral root and only considered the vertical water use patterns. Moreover, loessial soil is characterized with porous and homogeneous soil water retention (Huang et al., 2003). Thus, soil water sources in each soil layer were considered equal likelihood to plant water sources. The median values (50\% quartiles) were presented as the predictions of MixSIAR. The water sources from different soil layers were combined into three larger layers $(0-40,40-120$ and $120-300 \mathrm{~cm})$ to facilitate the subsequent analysis and comparison (Eggemeyer et al., 2009). Three layers were identified by the following (Wu et al., 2016):

(1) Shallow soil layer $(0-40 \mathrm{~cm})$ : the isotopic ratios in soil water and SWC were larger variability and were vulnerable to rainfall pulse and evaporation with season.

(2) Middle soil layer $(40-120 \mathrm{~cm})$ : the isotopic ratios in soil water and SWC were lower variations and milder monthly changes than that in the shallow soil layer.

(3) Deep soil layer $(120-300 \mathrm{~cm})$ : the isotopic ratios in soil water and SWC showed relatively stable variations.

\subsection{Data analyses}

In order to make stable isotope analysis more reasonable, two assumptions were made in this study (Brunel et al., 1995; Liu et al., 2011): (1) the isotopic composition in soil water was laterally homogeneous within the rooting area; and (2) the time delay between sampling and ascent of water transport in plant was not significant.

The Kolmogorov-Smirnov (K-S) test showed that the isotopic ratios of plant tissues and soil water met normal distribution. A two-way analysis of variance was conducted to detect the differences in the isotopic ratios of plant tissues between sampling dates and species. A one-way analysis of variance followed by post-hoc Tukey's least significant difference test $(p<0.05)$ was used to detect the differences in the isotopic compositions of soil water among the different depths for each species. All of the statistical analyses were conducted in SPSS 20.0 (SPSS Inc., Chicago, IL, USA).

\section{Results}

\subsection{Precipitation distribution and isotopic composition}

The total precipitation was $478 \mathrm{~mm}$ in the year of study (2016) and 91.35\% occurred during the growing season. In addition, the highest monthly precipitation was $184.40 \mathrm{~mm}$ in July, accounting for $38.94 \%$ of the year's total precipitation. The rainfall amount in 2016 was $24.40 \%$ greater than that of 2015 and $11.79 \%$ less than that of the multiyear mean in this region. The monthly variation was consistent with that of the multi-year mean (1960-2016) (Fig. 1). 
The isotopic composition of the rainwater presented a large fluctuation across the sampling dates. The $\delta^{18} \mathrm{O}$ ranged from -1.37 to $12.03 \%$, with an average of $-5.40 \%$, and $\delta^{2} \mathrm{H}$ ranged from -13.06 to $-90.25 \%$, with a mean value of $-36.92 \%$ (Fig. 1 ). The average monthly precipitation-weighted values of $\delta^{2} \mathrm{H}$ and $\delta^{18} \mathrm{O}$ were $-40.32 \%$ and $6.29 \%$, respectively. The distribution of isotopic values of the monthly weighted precipitation amounts during the sampling periods was bimodal with two peaks appearing in June and August (Fig. 2). For the greatest amount of precipitation, which occurred in July, the monthly weighted rainwater isotopic composition was $-62.03 \%$ for $\delta^{2} \mathrm{H}$ and $-8.83 \%$ o for $\delta^{18} \mathrm{O}$.

The local meteoric water line (LMWL) was fitted based on the precipitation data (Fig. 3). The slope and intercept of the LMWL were less than those of the global meteoric water line (GMWL) (Craig, 1961), indicating that the rainfall enriched isotope was caused by evaporation during the rainfall. Almost all of the isotopic values of the soil water from the three species' plots were plotted to the right of the LMWL, implying that soil water was derived from the precipitation and underwent enrichment associated with evaporation in this area. The $\delta^{2} \mathrm{H}$ and $\delta^{18} \mathrm{O}$ of soil water from $\mathrm{V}$. negundo plots were steeper compared with those of the two other species. The co-variation between $\delta^{2} \mathrm{H}$ and $\delta^{18} \mathrm{O}$ in the soil waters from $S$. bungeana and A. gmelinii plots were similar during the sampling periods (Fig. 3).

\subsection{Isotopic composition and variation in xylem water}

The isotopic values in xylem water varied among plant species and sampling periods. S. bungeana had the highest isotopic values, which ranged from -34.22 to $-66.52 \%$ ofor $\delta^{2} \mathrm{H}$, with an average of $-51.47 \%$, and $\delta^{18} \mathrm{O}$ ranged from -3.23 to $-8.08 \%$, with an average of $-5.84 \%$ o during the sampling periods. The average isotopic compositions for A. gmelinii and $V$. negundo were -56.22 and $-58.95 \%$ ofor $\delta^{2} \mathrm{H}$, respectively, and -7.15 and $-6.22 \%$ or for $\delta^{18} \mathrm{O}$, respectively. Averaging the xylem water isotope values over all sampling dates showed no significantly different $(p>0.05)$ among the three species, implying that all of the species absorbed water from similar soil layers. The isotopic compositions of xylem water of the three species were significantly different $(p<0.01)$ among sampling dates, suggesting that plant water uptake had significant temporal variability. Both $\delta^{2} \mathrm{H}$ and $\delta^{18} \mathrm{O}$ in the xylem water from $V$. negundo gradually decreased from May to August and increased in September. The trend of change in $\delta^{18} \mathrm{O}$ was consistent with that of $\delta^{2} \mathrm{H}$ in S. bungeana, in which the greatest values were in June and
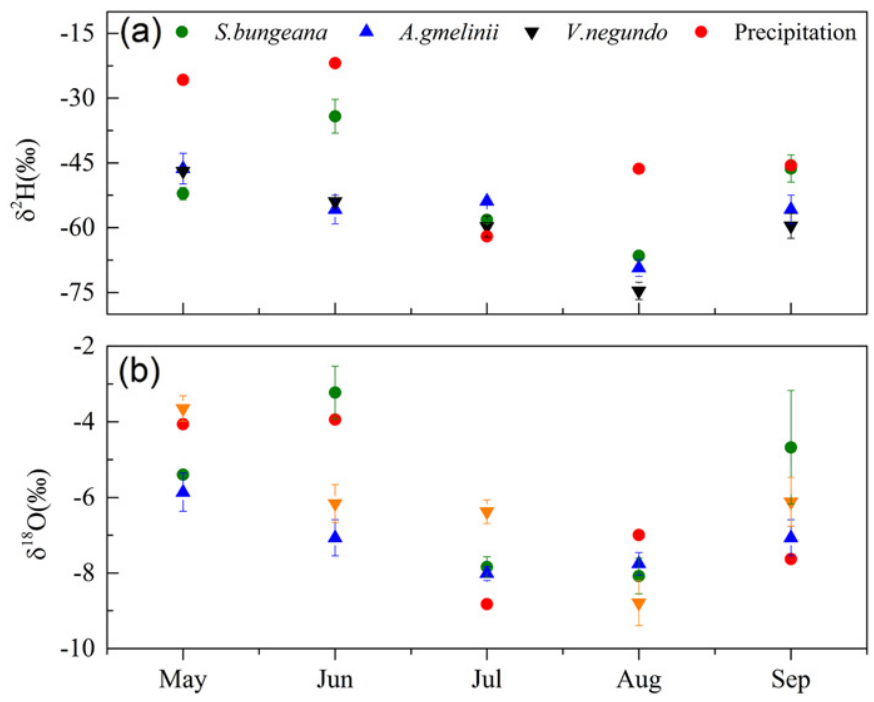

Fig. 2. Seasonal isotopic variations of (a) $\delta^{2} \mathrm{H}$ and (b) $\delta^{18} \mathrm{O}$ rainwater and xylem water in $S$. bungeana, A. gmelinii, V. negundo. Error bars represent the standard deviation $(\mathrm{N}=3)$. The $\delta^{2} \mathrm{H}$ and $\delta^{18} \mathrm{O}$ in rainwater represent the values of weighted averages per month. the lowest values were in August (Fig. 2). The isotopic compositions of $S$. bungeana and $A$. gmelinii were distributed close to those of soil water (Fig. 3), indicating that the two plants primarily obtained water from various soil horizons. However, the isotopic values of $V$. negundo were outside the soil mixing space, implying that hydrogen isotope fractionation may occur during water uptake. The isotopic values of xylem water were within the range of isotopic ratios in soil water from 0 to $120 \mathrm{~cm}$ soil layers (Fig. 3).

\subsection{Soil moisture and isotopic composition}

The SWC values in the plots of S. bungeana and A. gmelinii displayed similar temporal variations in each of the soil depths (Fig. 4). The SWC increased with soil depths above $40 \mathrm{~cm}$ soil horizons in May and August. However, the SWC exhibited the opposite trend in June, July and September. The SWC decreased from depths over $40 \mathrm{~cm}$ in the $V$. negundo plot, except for in August. The SWC from shallow soil layers $(0-40 \mathrm{~cm})$ was highly variable compared with those of the other layers during the sampling periods. In contrast, the SWC from the deeper soil layers (120-300 cm) was relatively stable and showed no distinct differences among species and sampling dates.

The isotopic composition of the soil water changed with the soil depths and plant species (Figs. 5,6 ). The $\delta^{18} \mathrm{O}$ of soil water in the three species plots were $-8.53 \pm 2.18 \%$ ofor S. bungeana, $-8.52 \pm$ $1.80 \%$ 。 for $A$. gmelinii and $-8.86 \pm 1.85 \%$ ofor $V$. negundo. The $\delta^{2} \mathrm{H}$ of the soil water in the S. bungeana, A. gmelinii and $V$. negundo plots were $-64.78 \pm 14.49 \%$ o, $-64.30 \pm 11.81 \%$ ond $-66.58 \pm 13.50 \%$, respectively. The isotopic ratios in soil water of the three species plots showed no significant differences $(p>0.05)$. The isotopic compositions in the soil water became more negative as the soil depth increased over the sampling period. During the sampling period, except for August, the shallow soil $(0-40 \mathrm{~cm})$ water had higher isotopic values and variances than those of middle $(40-120 \mathrm{~cm})$ and deep $(120-300 \mathrm{~cm})$ soil water. For $A$. gmelinii and $V$. negundo plots, both $\delta^{2} \mathrm{H}$ and $\delta^{18} \mathrm{O}$ in soil water were significantly different in shallow $(p<0.001)$, middle $(p<0.001)$ and deep $(p<0.001)$ soil layers during the sampling period. However, the isotopic compositions of the soil water in S. bungeana plots had significant differences, except for between shallow and middle soil water isotope $(p>0.05)$.

\subsection{Variations in the proportion of plant water uptake}

According to the graphical inference method, the three plant species derived most of their water from the $0-40 \mathrm{~cm}$ soil layers during the sampling period. The isotopic ratios of xylem water and soil water overlapped at several soil depths during July and August (Figs. 5, 6), implying that plants might derive water from several depths. Nevertheless, this graphical inference method only provided the main uptake depth and may lead to erroneous interpretation when plan water sources derived simultaneously from several soil layers.

The MixSIAR model predicted that the water uptake fraction of S. bungeana was $49.32 \pm 5.65 \%$ for shallow soil, $30.22 \pm 4.81 \%$ for middle soil and $20.56 \pm 5.10 \%$ for deep soil during the sampling period. Although $S$. bungeana mainly obtained water from shallow soil during the growing season, the proportional contribution of soil water varied over the sampling times. The fraction of water uptake from shallow soil was the greatest in May (55.20 $\pm 16.23 \%)$ and the lowest in August (40.00 $\pm 8.50 \%$ ) (Fig. 7). The proportions of water that S. bungeana derived from shallow and middle soils over the sampling periods showed no significant differences $(p>0.05)$. The proportions of water that A. gmelinii extracted from shallow, middle, deep soils during the sampling periods were $57.08 \pm 13.20 \%, 22.86 \pm 5.68 \%$ and $20.04 \pm 0.08 \%$, respectively. In July, the shallow soil contributed the most water $(74.20 \pm 15.20 \%)$, and the largest proportion of water $(33.10 \pm$ 7.09\%) was absorbed from deep soils in August (Fig. 7). Compared with A. gmelinii, $V$. negundo obtained a relative lower proportion of 

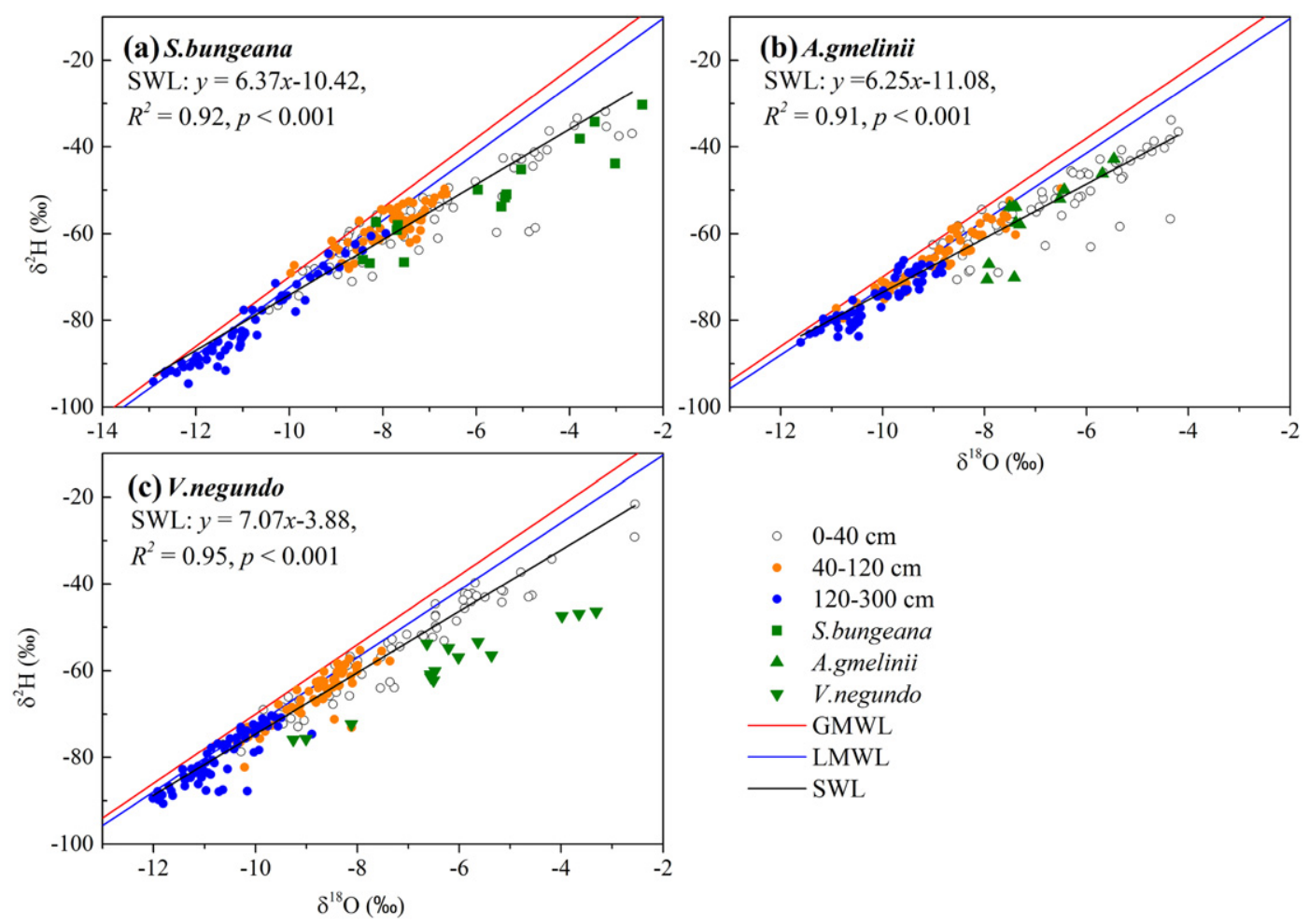

- $0-40 \mathrm{~cm}$

- $40-120 \mathrm{~cm}$

- $120-300 \mathrm{~cm}$

- S.bungeana

- A.gmelinii

$\checkmark$ V.negundo

- GMWL

LMWL

SWL

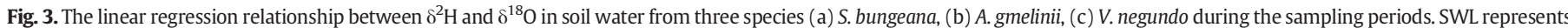

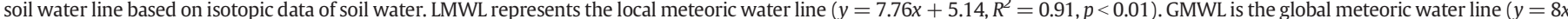
+10 ) (Craig, 1961). LMWL and GMWL are plotted in each panel for reference. The isotopic compositions of xylem water from three species were shown in the figure.

water from shallow soils $(49.24 \pm 14.14 \%)$ during the sampling dates. However, $V$. negundo absorbed the largest proportion of soil water $(24.62 \pm 5.56 \%)$ from 120 to $300 \mathrm{~cm}$ soil layer during the sampling periods. The percentage of water from deep soil increased from $14.50 \%$ in May to $42.40 \%$ in August (Fig. 7). For both A. gmelinii and V. negundo, the proportional contribution of soil water had significant difference from shallow $(p<0.05)$, middle $(p<0.05)$ and deep soil $(p<0.001)$ over the sampling periods.

\section{Discussion}

\subsection{Vertical gradient of isotopic composition in soil water}

The isotopic vertical gradient of soil water was primary influenced by two processes, evaporation and infiltration, simultaneously, with the mixing of old and new water from rainwater. The $\delta^{2} \mathrm{H}$ and $\delta^{18} \mathrm{O}$ in soil water became more depleted as the soil depth increased. The

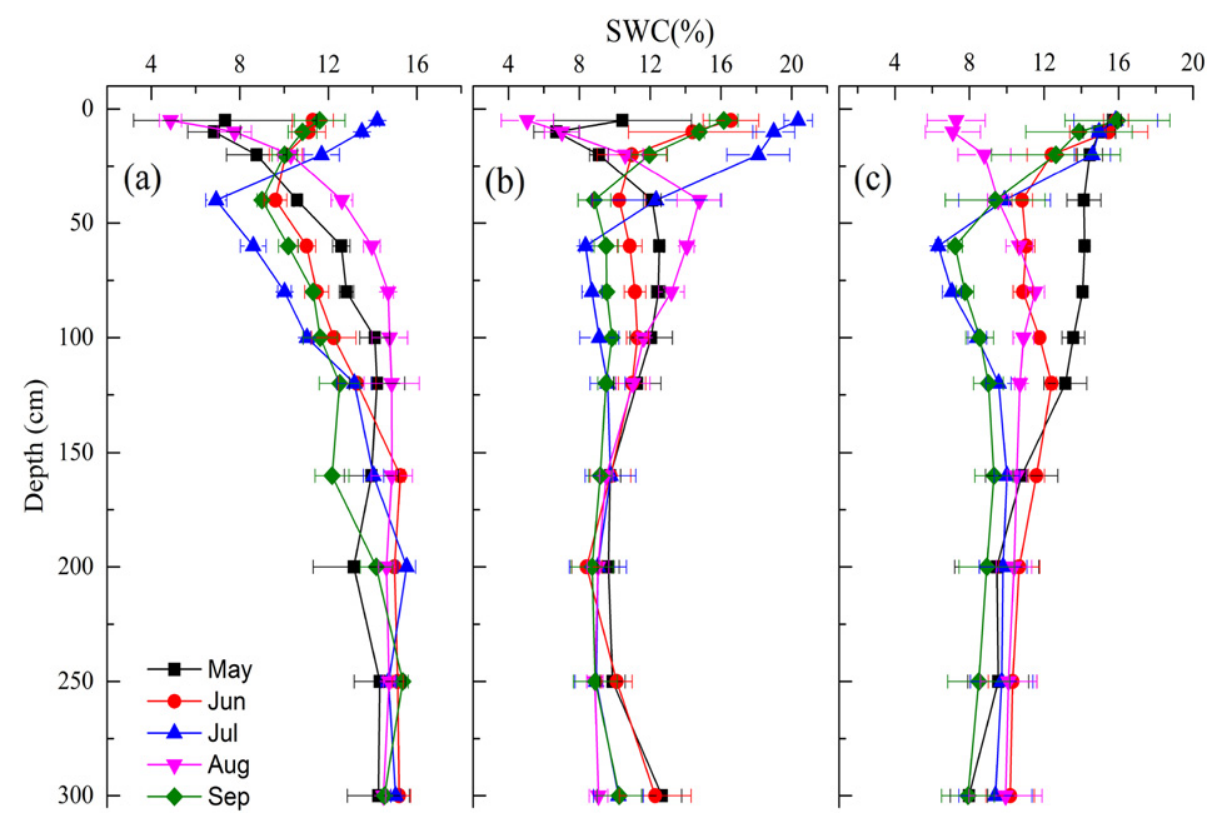

Fig. 4. Vertical profiles (0-300 cm) of gravimetric soil water content (SWC) (\%) from (a) S. bungeana, (b) A. gmelinii, (c) V. negundo. Error bars represent standard deviation (N = 3). 


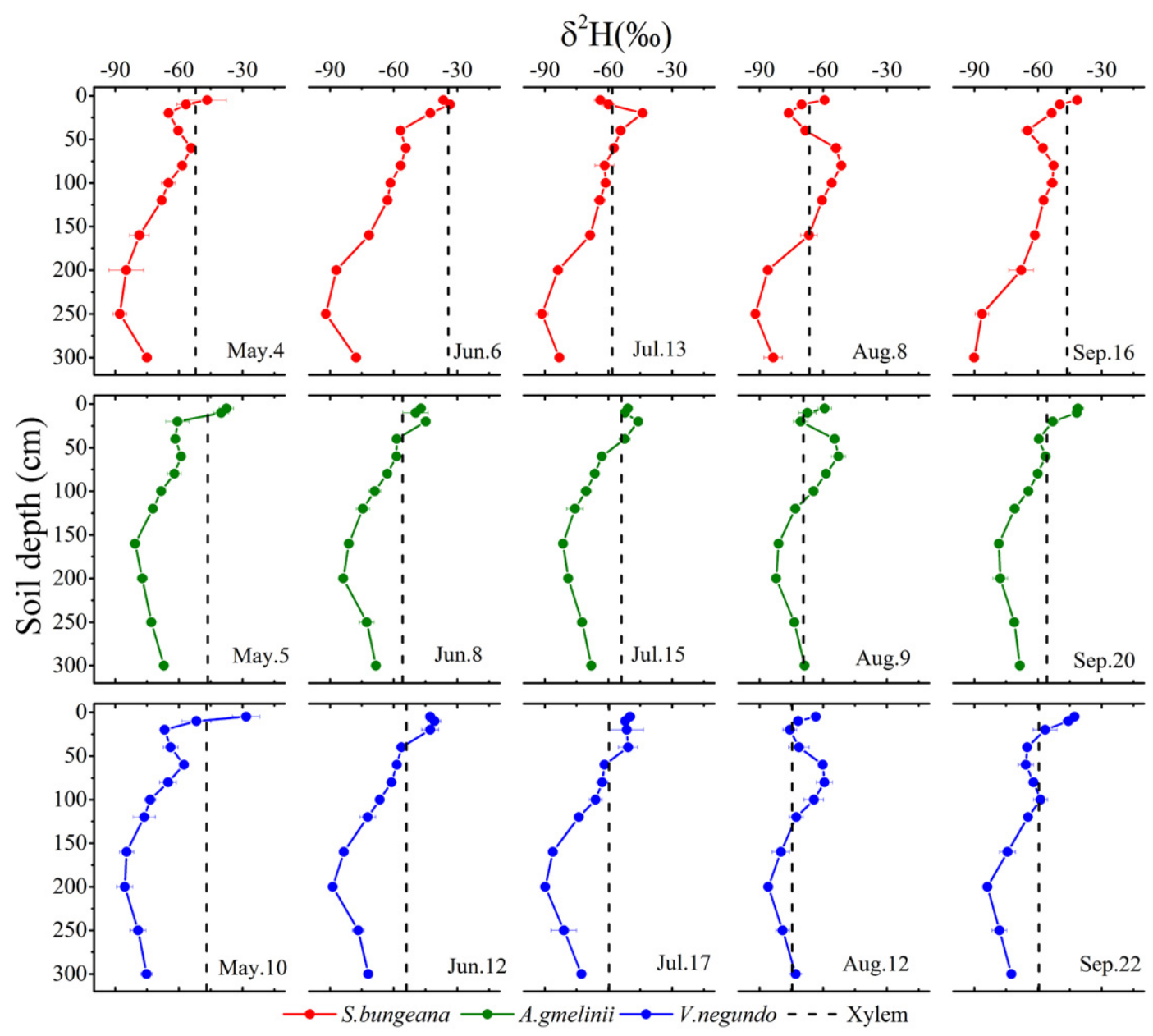

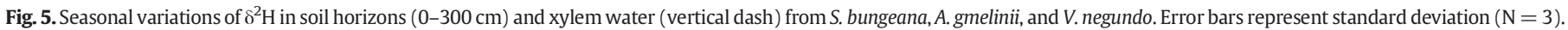

isotopic compositions in surface soil water were enriched as compared to deeper soil profiles in May, June and September (Figs. 5 and 6). This was attributed to less rainfall and more evaporation from the surface soil horizons (Gazis and Feng, 2004; Geris et al., 2017). Rainwater mixed with heavy isotope water in the surface soil and infiltrated through the soil matrix (Mathieu and Bariac, 1996; Brooks et al., 2009). However, this trend was reversed in July in surface soil because of the influence of recent rainfall having negative isotopic values, suggesting that precipitation was also an important factor controlling the isotopic compositions of soil water. The isotopic ratios of surface soil displayed larger variances than those of deep soil as the combined influences of evaporation and precipitation. Our findings were agreement with previous studies in arid and semi-arid ecosystems (Gazis and Feng, 2004; Wu et al., 2016).

Nevertheless, the $\delta^{2} \mathrm{H}$ and $\delta^{18} \mathrm{O}$ in water from 60 to $300 \mathrm{~cm}$ soil layers had less variation with both depths and sampling dates (Figs. 5 and 6). This pattern was consistent for the three species. The effect of evaporation was limited in deep soil and the groundwater was deep at the study site. Thus, the rainwater moved through soil pores that bypassed superficial soil in the soil profile (Eggemeyer et al., 2009; Gazis and Feng, 2004) and subsequently mixed with the stationary soil water and resulted in the vertical variation. A similar result was identified in a previous study (Brooks et al., 2009) in which the isotopes of the deep soil water were affected by infiltration mixed new and old water through preferential flow paths. In our study, there was no significant difference in soil water isotopes among three species, indicating that vegetation types had no influence on the isotopic ratios of soil water, because both plant water uptake and transpiration do not cause the isotopic fractionation of water (Brunel et al., 1995; Ehleringer and Dawson, 1992; Allison et al., 1983).

\subsection{Differences in seasonal water uptake patterns among species}

The isotopic compositions of xylem water in three species approached that of soil water from 0 to $120 \mathrm{~cm}$ soil (Fig. 3), suggesting that the potential water sources absorbed by plants derived mostly from 0 to $120 \mathrm{~cm}$ soil during the sampling periods. The MixSIAR outcomes indicated that S. bungeana derived $80 \%$ of its water from 0 to $120 \mathrm{~cm}$ soil during the growing season, and utilized the largest proportion (85\%) from 0 to $120 \mathrm{~cm}$ soil in July. In the semi-arid grasslands of Nebraska (USA), Eggemeyer et al. (2009) found that grasses predominantly utilized water from the upper soil layers $(5-50 \mathrm{~cm})$. The water uptake pattern of $S$. bungeana displayed the smallest fluctuation during the growing season, indicating a low level of plasticity in water source utilization.

Compared with S. bungeana, A. gmelinii extracted more water ( $60 \%)$ from shallow soil during the sampling period. The proportion of water absorbed by A. gmelinii from 0 to $120 \mathrm{~cm}$ soils showed no significant differences $(p=0.25>0.05)$ during the sampling periods. However, the proportions of water uptake from deep soils over the sampling dates presented significant differences $(p<0.001)$. A. gmelinii absorbed the largest proportion of water from shallow soil in July (74.2\%) (Fig. 7), indicating that this may be related to precipitation because of precipitation peak in July (Fig. 1), which resulted in ample surface soil water at this time. This result was similar to that of the previous study ( $\mathrm{Wu}$ et al., 2016) in which subshrubs primarily relied on water from 0 to 


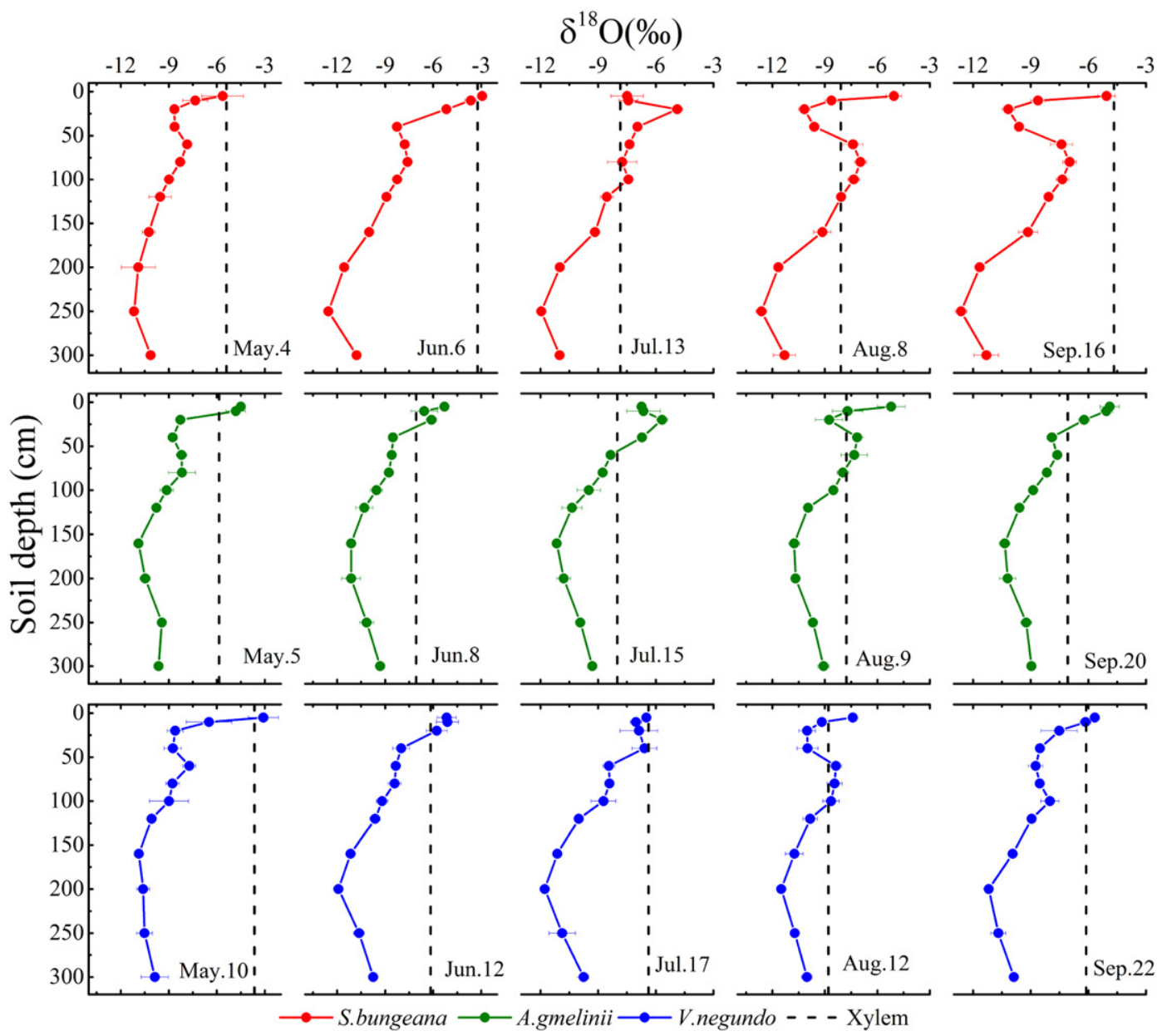

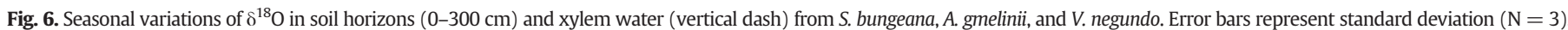

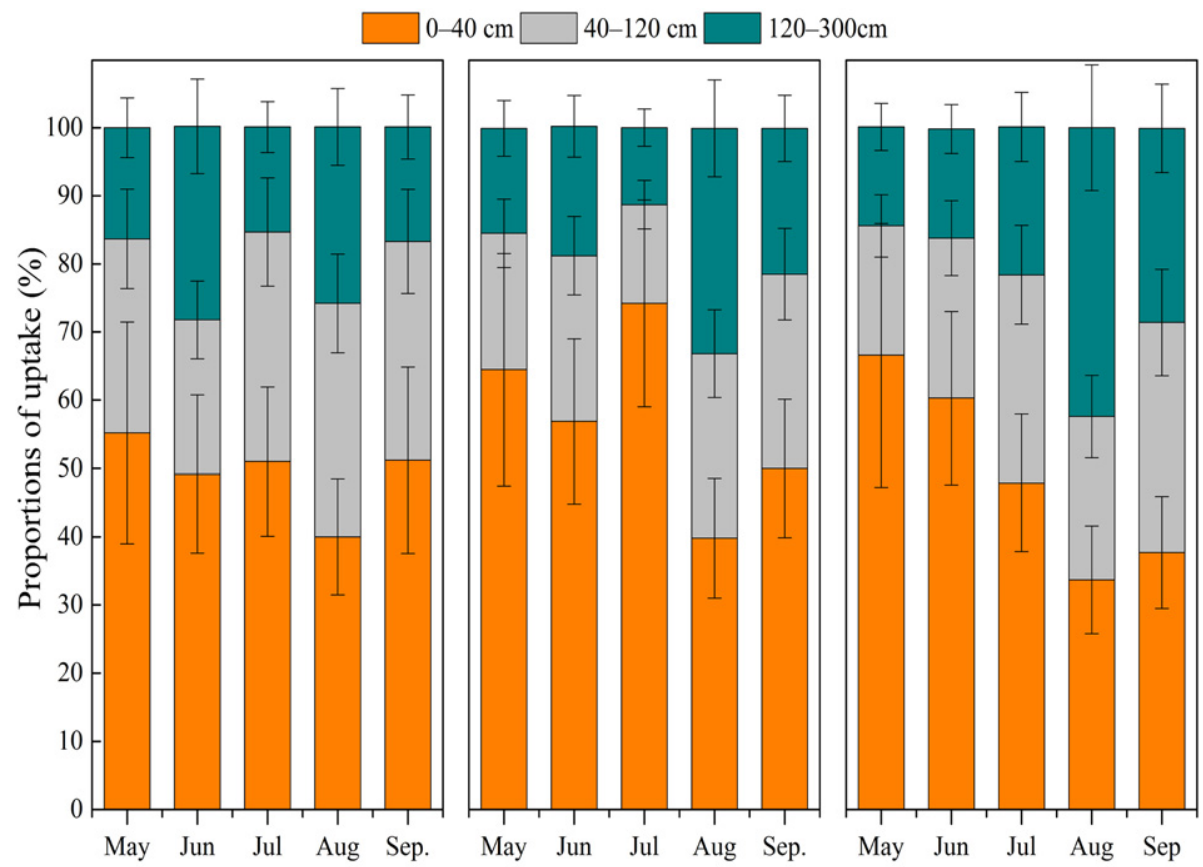
(a) S.bungeana
(b) A.gmelinii
(c) V.negundo

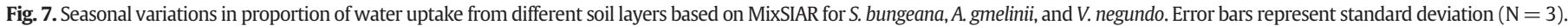


$30 \mathrm{~cm}$ soils throughout the growing season in a water limited ecosystem owing to the extensive horizontal root area. Asbjornsen et al. (2008) observed that two herbaceous species predominantly utilized water from 0 to $20 \mathrm{~cm}$ soil horizons and exhibited a relatively low range of ecological plasticity in water uptake. However, Lü et al. (2017) found that A. gmelinii absorbed water from 0 to $40 \mathrm{~cm}$ soil when SWC was sufficient, but from 40 to $80 \mathrm{~cm}$ when the shallow soil was dry.

In contrast, $V$. negundo derived the largest proportion of soil water from deep soil among the three species and progressively increased the contributory proportion of deep soil water during the growing season (Fig. 7). It displayed the greatest degree of plasticity in water uptake. This pattern may be attributed to the gradual increase in transpiration during the continuous growing season. Similar results were identified in other ecosystems (Asbjornsen et al., 2008) in which woody shrubs progressively increased their water uptake depths over the growing season.

Many plants species in arid and semi-arid ecosystems possess a functionally dimorphic root system, which has a zone of lateral roots that derive water from deep soil layers when surface water is unavailable, and another zone, which predominantly acquires water from surface soil during wet seasons (Dawson and Pate, 1996; Nie et al., 2010). The dimorphic root species switched to absorb water mainly from shallow to deep soil layers (Dawson and Pate, 1996; Yang et al., 2015). Plants that have dimorphic root systems have more competitive than those of solely depending on surface soil water in water limited environments (Ehleringer and Dawson, 1992; Yang et al., 2015). $V$. negundo had a set of lateral roots radiating out from the main root crown and one or more deeply penetrating tap (sinker) roots (Fig. 8). The extensive network of lateral roots was predominantly concentrated in the $60 \mathrm{~cm}$ soil layers with mostly root surface area (Fig. 9), allowing them to monopolize shallow moisture. The root surface area of $0-60 \mathrm{~cm}$ soil layer accounted for $81.31 \%$ of the total root surface area. In comparison, most of the roots and root surface areas were distributed in the surface soil layer for S. bungeana and A. gmelinii (Fig. 9). The root of $S$. bungeana was predominantly distributed in the $0-100 \mathrm{~cm}$ soil layer (Wang et al., 2010), which allowed them to absorb water sources from shallow soil layer during the growing season. Species that have shallow root systems might have more dense root hairs and absorption areas in surface soil horizons and contributed to derive more water from the surface layer (Schenk and Jackson, 2005). Water sources absorbed by plants from each soil layer were based on its respective proportion of fine roots (Ellsworth and Sternberg, 2015). Although the root of S. bungeana cannot reach $300 \mathrm{~cm}$, evidence from isotopes suggested that $20 \%$ of the water came from deep soil $(120-300 \mathrm{~cm})$. This may involve mechanisms for absorbing the deep soil water that needs further investigation. In a similar area, Wang et al. (2002) found the water utilization depth of $S$. bungeana reached $400 \mathrm{~cm}$ in a catchment of the Loess Plateau. Moreover, after a continuous 6-year soil water-monitoring

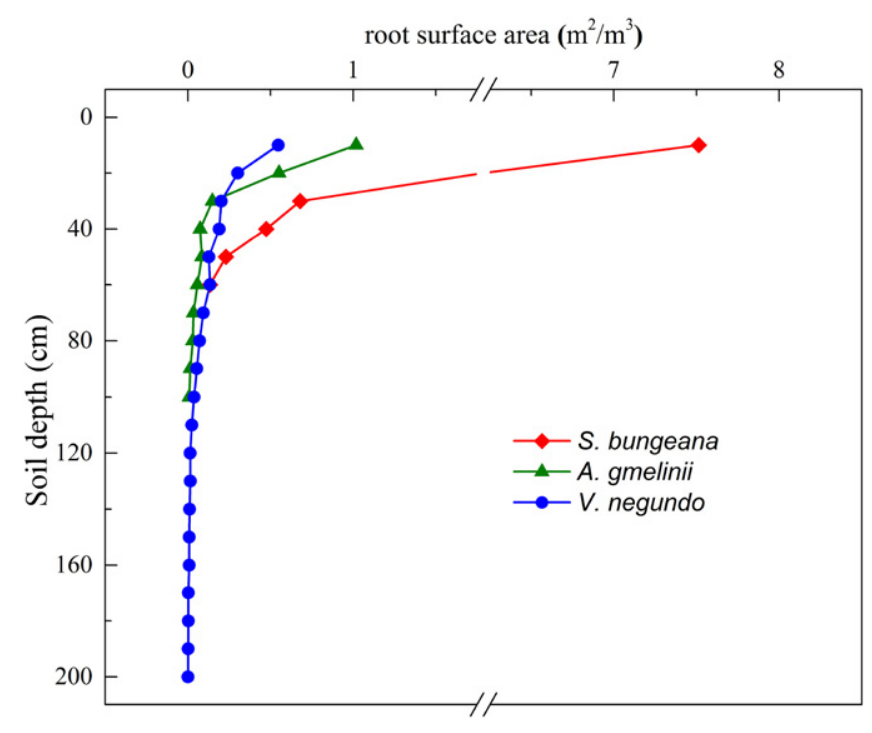

Fig. 9. Vertical distribution of root surface area $\left(\mathrm{m}^{2} / \mathrm{m}^{3}\right)$ for S. bungeana, A. gmelinii, and V. negundo.

project, Fan et al. (2016) reported that the maximum water uptake depths of S. bungeana on abandoned land in an erodible small watershed on the Loess Plateau was $300 \mathrm{~cm}$. In contrast, V. negundo possessed a deeper root system (Fig. 9) and was able to extract water from deep soil layers. Deep soil water contributed $22 \%$ of the total plant water sources for three species over the sampling periods. Deeper roots increased the tolerance to drought by increasing the probability to absorb deeper water sources when shallow soil water was low (Ellsworth and Sternberg, 2015; Markesteijn and Poorter, 2009). Moreover, some ecophysiological characters might enable plant species exhibited specific water uptake patterns in specific environment (Nie et al., 2010; Swemmer et al., 2006), such as more rapid recovery of photosynthesis after wilting, more rapid leaf turnover, greater allocation to roots, reduced allocation to flowering.

\subsection{Implications}

Although there is relatively low precipitation in arid and semi-arid regions, individual rainfall events cause water source enrichments in the short-term, which play important roles in shaping plant adaptation in water use strategies (Schwinning and Ehleringer, 2001). Plant species that switch water uptake patterns can avoid interspecific competition with shallow rooted species at the same site and have a greater probability of survival owing to their improved competitiveness by adapting to droughts in the semi-arid regions (Ehleringer and Dawson, 1992).
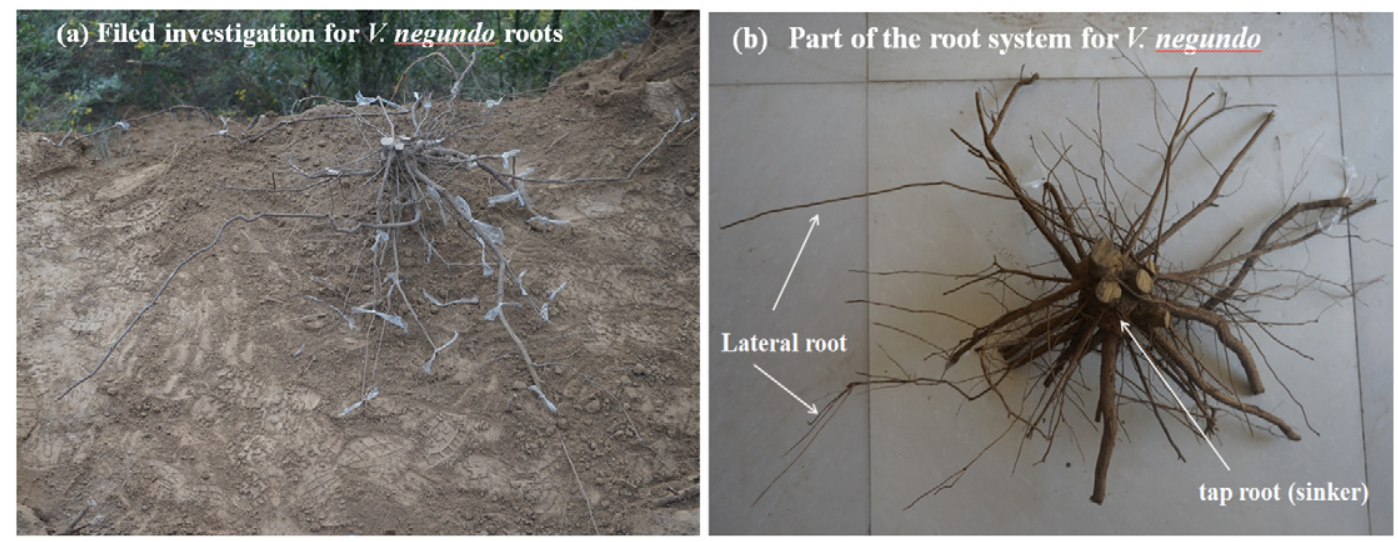

Fig. 8. Picture of field investigation for $V$. negundo roots. The view of the entire root system (fine roots were invisible) (a) a zoom-in view for lateral and tap roots (b). 
Some deciduous species adapted to droughts by different strategies. One was to avoid drought by losing their leaves and remaining dormant in the dry season (Ellsworth and Sternberg, 2015), and another was to switch water sources absorbed by plants depending on water available (Wu et al., 2016; Liu et al., 2010). V. negundo was deciduous woody specie and progressively switched its water source during the growing season. This flexible water use strategy will be more advantageous under the predicted increasingly frequent drought events of the future and will promote population growth and the plant's survival probability. S. bungeana and A. gmelinii mainly derived water from surface soil layers and had lower variation levels during the whole growing season. This demonstrated that shallow-rooted plant species, especially A. gmelinii, were sensitive to precipitation. The roots were beneficial for the plant to make better use of precipitation. Extracting shallow water in semiarid ecosystems might exhibit a high tolerance for limited water source environments, which is dependent on the ability of fine roots to quickly switch absorption patterns in response to precipitation pulses and water shortages (Asbjornsen et al., 2008). The combinations of different water uptake patterns of plant species might be more conducive to ecological restoration. In this manner, $V$. negundo was conducive to being combined with $S$. bungeana or $A$. gmelinii. In addition, the variation in water uptake patterns could lead to ecological niches separation complementary uses of resources and, in turn, facilitate species coexistence and ecosystem functions (Asbjornsen et al., 2008). Stable isotope technology provided insights into plant species selection and management during ecological restoration in the arid and semi-arid ecosystems. More physiological and ecological characteristics coupled with the continuous monitoring of stable isotopic ratios may provide further insights into water uptake patterns.

\section{Conclusions}

The MixSIAR model based on dual stable isotopes $\delta^{2} \mathrm{H}$ and $\delta^{18} \mathrm{O}$ was applied to determine the seasonal variations of water uptake patterns of a grass (S. bungeana), a subshrub (A. gmelinii) and a shrub (V. negundo) on the Chinese Loess Plateau. The isotopic compositions of the shallow soil water were more enriched and had more variation than that of the deep soil water. The MixSIAR model predicted that $S$. bungeana and A. gmelinii predominantly derived $80 \%$ of water from 0 to $120 \mathrm{~cm}$ soil layers and displayed a relatively low level of variation during the growing season. However, $V$. negundo exhibited a distinct water uptake pattern that progressively switched its water source from shallow to deep soil horizons as the season progressed, indicating a greater degree of ecological plasticity. This was mainly attributed to the functionally dimorphic root system. The flexible water uptake patterns of plants might facilitate plant species making full use of water and nutritional sources, adapting to the changeable environment. This study provides a useful method that identified partitioning and proportional contributions of water resources, and the research results will be significant for vegetation restoration in the arid and semi-arid ecosystems.

\section{Acknowledgements}

This study was financially supported by the National Natural Science Foundation of China (NSFC 41390462 and 41230745). We are grateful to Jianbo Liu, Weiwei Fang, and Jianye Li for the assistance in the field experiments. We thank three anonymous reviewers for their time spent helping to improve the manuscript.

\section{References}

Allison, G., Barnes, C., Hughes, M., Leaney, F., 1983. Effect of climate and vegetation on oxygen-18 and deuterium profiles in soils. Isot. Hydrol. 105-123.

Asbjornsen, H., Shepherd, G., Helmers, M., Mora, G., 2008. Seasonal patterns in depth of water uptake under contrasting annual and perennial systems in the Corn Belt Region of the Midwestern U.S. Plant Soil 308, 69-92.
Barnard, R.L., de Bello, F., Gilgen, A.K., Buchmann, N., 2006. The $\delta^{18} \mathrm{O}$ of root crown water best reflects source water $\delta^{18} \mathrm{O}$ in different types of herbaceous species. Rapid Commun. Mass Spectrom. 20, 3799-3802.

Brand, W.A., Geilmann, H., Crosson, E.R., Rella, C.W., 2009. Cavity ring-down spectroscopy versus high-temperature conversion isotope ratio mass spectrometry; a case study on $\delta^{2} \mathrm{H}$ and $\delta^{18} \mathrm{O}$ of pure water samples and alcohol/water mixtures. Rapid Commun. Mass Spectrom. 23, 1879-1884.

Brooks, J.R., Barnard, H.R., Coulombe, R., McDonnell, J.J., 2009. Ecohydrologic separation of water between trees and streams in a Mediterranean climate. Nat. Geosci. 3 100-104.

Brunel, J.-P., Walker, G.R., Kennett-Smith, A.K., 1995. Field validation of isotopic procedures for determining sources of water used by plants in a semi-arid environment. J. Hydrol. 167, 351-368.

Chen, L., Huang, Z., Gong, J., Fu, B., Huang, Y., 2007. The effect of land cover/vegetation on soil water dynamic in the hilly area of the loess plateau, China. Catena 70, 200-208.

Chen, H., Shao, M., Li, Y., 2008. Soil desiccation in the Loess Plateau of China. Geoderma 143, 91-100.

Chen, Y., Wang, K., Lin, Y., Shi, W., Song, Y., He, X., 2015. Balancing green and grain trade. Nat. Geosci. 8, 739-741.

Chen, H., Hu, K., Nie, Y., Wang, K., 2017. Analysis of soil water movement inside a footslope and a depression in a karst catchment, Southwest China. Sci Rep 7, 2544.

Craig, H., 1961. Isotopic variations in meteoric waters. Science 133, 1702-1703.

Dawson, T.E., 1996. Determining water use by trees and forests from isotopic, energy balance and transpiration analyses: the roles of tree size and hydraulic lift. Tree Physiol. 16

Dawson, T.E., Ehleringer, J.R., 1991. Streamside trees that do not use stream water. Nature 350, 335-337.

Dawson, T.E., Pate, J.S., 1996. Seasonal water uptake and movement in root systems of Australian phraeatophytic plants of dimorphic root morphology: a stable isotope investigation. Oecologia 107, 13-20.

Dawson, T.E., Mambelli, S., Plamboeck, A.H., Templer, P.H., Tu, K.P., 2002. Stable isotopes in plant ecology. Annu. Rev. Ecol. Syst. 507-559.

Delzon, S., Loustau, D., 2005. Age-related decline in stand water use: sap flow and transpiration in a pine forest chronosequence. Agric. For Meteorol. 129, 105-119.

Eggemeyer, K.D., Awada, T., Harvey, F.E., Wedin, D.A., Zhou, X., Zanner, C.W., 2009. Seasonal changes in depth of water uptake for encroaching trees Juniperus virginiana and Pinus ponderosa and two dominant C4 grasses in a semiarid grassland. Tree Physiol. 29, 157-169.

Ehleringer, J., Dawson, T., 1992. Water uptake by plants: perspectives from stable isotope composition. Plant Cell Environ. 15, 1073-1082.

Ehleringer, J.R., Phillips, S.L., Schuster, W.S., Sandquist, D.R., 1991. Differential utilization of summer rains by desert plants. Oecologia 88, 430-434.

Ellsworth, P.Z., Sternberg, L.S., 2015. Seasonal water use by deciduous and evergreen woody species in a scrub community is based on water availability and root distribution. Ecohydrology 8, 538-551.

Ellsworth, P.Z., Williams, D.G., 2007. Hydrogen isotope fractionation during water uptake by woody xerophytes. Plant Soil 291, 93-107.

Evaristo, J., McDonnell, J.J., 2017. Prevalence and magnitude of groundwater use by vegetation: a global stable isotope meta-analysis. Sci Rep 7, 4110.

Evaristo, J., McDonnell, J.J., Scholl, M.A., Bruijnzeel, L.A., Chun, K.P., 2016. Insights into plant water uptake from xylem-water isotope measurements in two tropical catchments with contrasting moisture conditions. Hydrol. Process. 30, 3210-3227.

Evaristo, J., McDonnell, J.J., Clemens, J., 2017. Plant source water apportionment using stable isotopes: a comparison of simple linear, two-compartment mixing model approaches. Hydrol. Process. http://dx.doi.org/10.1002/hyp.11233.

Fan, J., Wang, Q. Jones, S.B., Shao, M., 2016. Soil water depletion and recharge under different land cover in China's Loess Plateau. Ecohydrology 9, 396-406.

Gao, X., Wu, P., Zhao, X., Shi, Y., Wang, J., Zhang, B., 2011. Soil moisture variability along transects over a well-developed gully in the Loess Plateau, China. Catena 87 357-367.

Gazis, C., Feng, X., 2004. A stable isotope study of soil water: evidence for mixing and preferential flow paths. Geoderma 119, 97-111.

Geris, J., Tetzlaff, D., McDonnell, J.J., Soulsby, C., 2017. Spatial and temporal patterns of soil water storage and vegetation water use in humid northern catchments. Sci. Total Environ. 595, 486-493.

Grossiord, C., Sevanto, S., Dawson, T.E., Adams, H.D., Collins, A.D., Dickman, L.T., et al., 2017. Warming combined with more extreme precipitation regimes modifies the water sources used by trees. New Phytol. 213, 584-596.

Hardanto, A., Röll, A., Hölscher, D., 2017. Tree soil water uptake and transpiration in mono-cultural and jungle rubber stands of Sumatra. For. Ecol. Manag. 397, 67-77.

Howard, J., Merrifield, M., 2010. Mapping groundwater dependent ecosystems in California. PLoS One 5, e11249.

Huang, M., Dang, T., Gallichand, J., Goulet, M., 2003. Effect of increased fertilizer applications to wheat crop on soil-water depletion in the Loess Plateau, China. Agric. Water Manag. 58, 267-278.

Huang, T., Pang, Z., Edmunds, W.M., 2013. Soil profile evolution following land-use change: implications for groundwater quantity and quality. Hydrol. Process. 27 1238-1252.

Jian, S., Zhao, C., Fang, S., Yu, K., 2015. Effects of different vegetation restoration on soil water storage and water balance in the Chinese Loess Plateau. Agric. For. Meteorol. 206, 85-96.

Knight, J.H., 1999. Root distributions and water uptake patterns in Eucalypts and other species. In: Landsberg, J. (Ed.), The Ways Trees Use Water. RIRDC, AU, pp. 55-85.

Li, Y., Poesen, J., Yang, J., Fu, B., Zhang, J., 2003. Evaluating gully erosion using 137Cs and $210 \mathrm{~Pb} / 137 \mathrm{Cs}$ ratio in a reservoir catchment. Soil Tillage Res. 69, 107-115.

Li, S.G., Romero-Saltos, H., Tsujimura, M., Sugimoto, A., Sasaki, L., Davaa, G., et al., 2007. Plant water sources in the cold semiarid ecosystem of the upper Kherlen River catchment in Mongolia: a stable isotope approach. J. Hydrol. 333, 109-117.

Lin, G.H., Sternber, L.S.L., 1993. Hydrogen isotopic fractionation by plant roots during water uptake in coastal wetland plants. Stable Isotopes and Plant Carbon/Water Relations. Academic Press, New York, pp. 497-510. 
Liu, W., Liu, W., Li, P., Duan, W., Li, H., 2010. Dry season water uptake by two dominant canopy tree species in a tropical seasonal rainforest of Xishuangbanna, SW China. Agric. For. Meteorol. 150, 380-388.

Liu, Y., Xu, Z., Duffy, R., Chen, W., An, S., Liu, S., et al., 2011. Analyzing relationships among water uptake patterns, rootlet biomass distribution and soil water content profile in a subalpine shrubland using water isotopes. European Journal of Soil Biology]->Eur. J. Soil Biol. 47, 380-386.

Liu, Y., Fu, B., Lü, Y., Wang, Z., Gao, G., 2012. Hydrological responses and soil erosion potential of abandoned cropland in the Loess Plateau, China. Geomorphology 138, 404-414.

Lü, T., Zhao, X., Gao, X., Pan, Y., 2017. Soil water use strategy of dominant species in typical natural and planted shrubs in loess hilly region. Chin. J. Plant Ecol. 41, 175-185.

Ma, Y., Song, X., 2016. Using stable isotopes to determine seasonal variations in water uptake of summer maize under different fertilization treatments. Sci. Total Environ. 550, 471-483.

Mares, R., Barnard, H.R., Mao, D., Revil, A., Singha, K., 2016. Examining diel patterns of soil and xylem moisture using electrical resistivity imaging. J. Hydrol. 536, 327-338.

Markesteijn, L., Poorter, L., 2009. Seedling root morphology and biomass allocation of 62 tropical tree species in relation to drought- and shade-tolerance. J. Ecol. 97, 311-325.

Mathieu, R., Bariac, T., 1996. An isotopic study $\left({ }^{2} \mathrm{H}\right.$ and $\left.{ }^{18} \mathrm{O}\right)$ of water movements in clayey soils under a semiarid climate. Water Resour. Res. 32, 779-789.

McCole, A.A., Stern, L.A., 2007. Seasonal water use patterns of Juniperus ashei on the Edwards Plateau, Texas, based on stable isotopes in water. J. Hydrol. 342, 238-248.

Meißner, M., Köhler, M., Schwendenmann, L., Hölscher, D., 2012. Partitioning of soil water among canopy trees during a soil desiccation period in a temperate mixed forest. Biogeosciences 9, 3465-3474.

Moreno-de Las Heras, M., Espigares, T., Merino-Martín, L., Nicolau, J., 2011. Water-related ecological impacts of rill erosion processes in Mediterranean-dry reclaimed slopes. Catena 84, 114-124.

Moreno-Gutiérrez, C., Battipaglia, G., Cherubini, P., Delgado Huertas, A., Querejeta, J.I. Thompson, K., 2015. Pine afforestation decreases the long-term performance of understorey shrubs in a semi-arid Mediterranean ecosystem: a stable isotope approach. Funct. Ecol. 29, 15-25.

Nie, Y.P., Chen, H.S., Wang, K.L., Tan, W., Deng, P.Y., Yang, J., 2010. Seasonal water use patterns of woody species growing on the continuous dolostone outcrops and nearby thin soils in subtropical China. Plant Soil 341, 399-412.

Porporato, A., Daly, E., Rodriguez-Iturbe, I., 2004. Soil water balance and ecosystem response to climate change. American Naturalist]->Am. Nat. 164, 625-632.

Prechsl, U.E., Burri, S., Gilgen, A.K., Kahmen, A., Buchmann, N., 2015. No shift to a deeper water uptake depth in response to summer drought of two lowland and sub-alpine C(3)-grasslands in Switzerland. Oecologia 177, 97-111.

Priyadarshini, K.V.R., Prins, H.H.T., de Bie, S., Heitkönig, I.M.A., Woodborne, S., Gort, G., et al., 2016. Seasonality of hydraulic redistribution by trees to grasses and changes in their water-source use that change tree-grass interactions. Ecohydrology 9, 218-228.

Querejeta, J.I., Estrada-Medina, H., Allen, M.F., Jimenez-Osornio, J.J., 2007. Water source partitioning among trees growing on shallow karst soils in a seasonally dry tropica climate. Oecologia 152, 26-36.

Rothfuss, Y., Javaux, M., 2017. Reviews and syntheses: isotopic approaches to quantify root water uptake: a review and comparison of methods. Biogeosciences 14, 2199.

Schenk, H.J., Jackson, R.B., 2005. Mapping the global distribution of deep roots in relation to climate and soil characteristics. Geoderma 126, 129-140.

Schultz, N.M., Griffis, T.J., Lee, X., Baker, J.M., 2011. Identification and correction of spectral contamination in ${ }^{2} \mathrm{H} /{ }^{1} \mathrm{H}$ and ${ }^{18} \mathrm{O} /{ }^{16} \mathrm{O}$ measured in leaf, stem, and soil water. Rapid Commun. Mass Spectrom. 25, 3360-3368.
Schwendenmann, L., Pendall, E., Sanchez-Bragado, R., Kunert N., Hölscher, D., 2015. Tree water uptake in a tropical plantation varying in tree diversity: interspecific differences, seasonal shifts and complementarity. Ecohydrology 8, 1-12.

Schwinning, S., Ehleringer, J.R., 2001. Water use trade-offs and optimal adaptations to pulse-driven arid ecosystems. J. Ecol. 89, 464-480.

Silvertown, J., Araya, Y., Gowing, D., Cornwell, W., 2015. Hydrological niches in terrestrial plant communities: a review. J. Ecol. 103, 93-108.

Sprenger, M., Leistert, H., Gimbel, K., Weiler, M., 2016. Illuminating hydrological processes at the soil-vegetation-atmosphere interface with water stable isotopes. Rev. Geophys. 54, 674-704.

Stock, B.C., Semmens, B.X., 2013. MixSIAR GUI User Manual, Version 3.1. http://conserver. iugocafe.org/user/brice.semmens/MixSIAR.

Swaffer, B.A., Holland, K.L., Doody, T.M., Li, C., Hutson, J., 2014. Water use strategies of two co-occurring tree species in a semi-arid karst environment. Hydrol. Process. 28, 2003-2017.

Swemmer, A.M., Knapp, A.K., Smith, M.D., 2006. Growth responses of two dominant C4 grass species to altered water availability. Int. J. Plant Sci. 167, 1001-1010.

Thorburn, P.J., Ehleringer, J.R., 1995. Root water uptake of field-growing plants indicated by measurements of natural-abundance deuterium. Plant Soil 177, 225-233.

Valladares, F., Gianoli, E., Gómez, J.M., 2007. Ecological limits to plant phenotypic plasticity. New Phytol. 176, 749-763.

Vargas, A.I., Schaffer, B., Yuhong, L., Sternberg, LdSL, 2017. Testing plant use of mobile vs immobile soil water sources using stable isotope experiments. New Phytol. 215, 582-594.

Wang, G., Liu, G., Chang, X., Xu, M., 2002. A study on the effect of soil water on vegetation rehabilitation in watershed of loss hilly area. J. Nat. Resour. 17, 339-344.

Wang, Y., Ma, Shao, Shao, H., 2010. A preliminary investigation of the dynamic characteristics of dried soil layers on the Loess Plateau of China. J. Hydrol. 381, 9-17.

Wang, S., Fu, B.J., Gao, G.Y., Yao, X.L., Zhou, J., 2012. Soil moisture and evapotranspiration of different land cover types in the Loess Plateau, China. Hydrol. Earth Syst. Sci. 16, 2883-2892

West, A.G., Goldsmith, G.R., Brooks, P.D., Dawson, T.E., 2010. Discrepancies between isotope ratio infrared spectroscopy and isotope ratio mass spectrometry for the stable isotope analysis of plant and soil waters. Rapid Commun. Mass Spectrom. 24, 1948-1954.

Wu, Y., Zhou, H., Zheng, X.J., Li, Y., Tang, L.S., 2014. Seasonal changes in the water use strategies of three co-occurring desert shrubs. Hydrol. Process. 28, 6265-6275.

Wu, H., Li, X.Y., Jiang, Z., Chen, H., Zhang, C., Xiao, X., 2016. Contrasting water use pattern of introduced and native plants in an alpine desert ecosystem, Northeast QinghaiTibet Plateau, China. Sci. Total Environ. 542, 182-191.

Xu, H., Li, Y., 2006. Water-use strategy of three central Asian desert shrubs and their responses to rain pulse events. Plant Soil 285, 5-17.

Yang, Y., Fu, B., 2017. Soil water migration in the unsaturated zone of semiarid region in China from isotope evidence. Hydrol. Earth Syst. Sci. 21, 1757-1767.

Yang, B., Wen, X.F., Sun, X.M., 2015. Seasonal variations in depth of water uptake for a subtropical coniferous plantation subjected to drought in an East Asian monsoon region. Agric. For Meteorol. 201, 218-228.

Zhang, Z.Q., Evaristo, J., Li, Z., Si, B.C., McDonnell, J.J., 2017. Tritium analysis shows apple trees may be transpiring water several decades old. Hydrol. Process. 31, 1196-1201.

Zhao, L., Xiao, H., Zhou, J., Wang, L., Cheng, G., Zhou, M., et al., 2011. Detailed assessment of isotope ratio infrared spectroscopy and isotope ratio mass spectrometry for the stable isotope analysis of plant and soil waters. Rapid Commun. Mass Spectrom. 25, $3071-3082$ 